\title{
Role of the HI haplotype of microtubule-associated protein tau (MAPT) gene in Greek patients with Parkinson's disease
} Nikolaos Refenes ${ }^{* 1,2}$, Juliane Bolbrinker ${ }^{2}$, Georgios Tagaris ${ }^{3}$,
Antonio Orlacchio ${ }^{4,5}$, Nikolaos Drakoulis ${ }^{1}$ and Reinhold Kreutz

\begin{abstract}
Address: ${ }^{1}$ School of Pharmacy, Department of Pharmaceutical Technology, National and Kapodistrian University of Athens, Athens, Greece, 2Institute of Clinical Pharmacology and Toxicology, Charité - Universitätsmedizin Berlin, Berlin, Germany, ${ }^{3}$ Department of Neurology, "G. Gennimatas" General Hospital, Athens, Greece, ${ }^{4}$ Laboratory of Neurogenetics, CERC-IRCCS Santa Lucia, Rome, Italy and ${ }^{5}$ Department of Neuroscience, University of Rome "Tor Vergata", Rome, Italy

Email: Nikolaos Refenes* - nrefenes@pharm.uoa.gr; Juliane Bolbrinker - juliane.bolbrinker@charite.de; Georgios Tagaris - tagaris@otenet.gr; Antonio Orlacchio - a.orlacchio@hsantalucia.it; Nikolaos Drakoulis - drakoulis@pharm.uoa.gr; Reinhold Kreutz - reinhold.kreutz@charite.de

* Corresponding author
\end{abstract}

Published: 28 June 2009

BMC Neurology 2009, 9:26 doi:10.1 186/147|-2377-9-26
Received: 10 February 2009

Accepted: 28 June 2009

This article is available from: http://www.biomedcentral.com/147I-2377/9/26

(C) 2009 Refenes et al; licensee BioMed Central Ltd.

This is an Open Access article distributed under the terms of the Creative Commons Attribution License (http://creativecommons.org/licenses/by/2.0), which permits unrestricted use, distribution, and reproduction in any medium, provided the original work is properly cited.

\begin{abstract}
Background: The extended tau haplotype $(\mathrm{HI})$ that covers the entire human microtubuleassociated protein tau (MAPT) gene has been implicated in Parkinson's disease (PD). Nevertheless, controversial results, such as two studies in Greek populations with opposite effects, have been reported. Therefore, we set out to determine whether the $\mathrm{HI}$ haplotype and additional single nucleotide polymorphisms (SNPs) included in $\mathrm{HI}$ are associated with PD in a sample of Greek patients.
\end{abstract}

Methods: We analysed MAPT haplotypes in cohorts of 122 patients and 123 controls of Greek origin, respectively. SNP genotyping was performed with Taqman assays and genotyping results were confirmed by sequencing.

Results: The presence of the $\mathrm{HI}$ haplotype was significantly associated with PD (odds ratio for $\mathrm{HIHI}$ vs. $\mathrm{HIH} 2$ and $\mathrm{H} 2 \mathrm{H} 2$ : $1.566 ; 95 \% \mathrm{Cl}$ : $1.137-2.157 ; P=0.006$ ) and remained so after adjustment for sex. Further analysis of $\mathrm{HI}$ sub-haplotypes with three single nucleotide polymorphisms (rs242562, rs2435207 and rs3785883) demonstrated no significant association with PD.

Conclusion: Our data support the overall genetic role of MAPT and the HI haplotype for PD susceptibility in Greek patients. However, the previously supported association of $\mathrm{HI}$ subhaplotypes with PD could not be confirmed in our study.

\section{Background}

Parkinson's disease (PD) is the most common movement disorder that becomes more prevalent with advanced age and represents the second most common neurodegenerative disorder after Alzheimer's disease (AD) [1]. PD is characterized by four cardinal symptoms: resting tremor, bradykinesia, muscle rigidity and postural instability [2]. The degeneration of the nigrostriatal dopaminergic neurons causes symptoms of PD and one of the main neuropathological features of the disease consists of 
intracellular proteinaceous inclusions called Lewy bodies [3]. Aggregation and fibrillization of the $\alpha$-synuclein protein, which is the main component of Lewy bodies, represent key events in the pathogenesis of $\mathrm{PD},[4]$ and the disease is classified as an $\alpha$-synucleinopathy.

In addition, a disease mechanism based on the protein tau has been proposed in PD $[5,6]$. Tau proteins are a group of phosphorylated neuronal microtubule-associated proteins that bind to microtubules and promote microtubule assembly and stabilization. They are expressed in neurons and they are particularly abundant in axons [7]. Due to the proposed interactions of $\alpha$-synuclein and tau protein and their abnormal intracellular aggregation in neurodegenerative diseases, $[5,6]$ the analysis of microtubule-associated protein tau (MAPT) gene as a genetic susceptibility factor for PD has been of interest.

The MAPT gene is encoded on chromosome $17 \mathrm{q} 21$ in the centre of a $900 \mathrm{~kb}$ fragment between two extended haplotypes, $\mathrm{H} 1$ and $\mathrm{H} 2$, which cover the entire MAPT gene [8]. $\mathrm{H} 1$ and $\mathrm{H} 2$ haplotypes differ in orientation, [9] and do not recombine [10]. Chromosome 17q, containing the MAPT gene, was one of the regions given the highest logarithm of odds (lod) scores in the genomic screen for PD conducted by Scott et al [11]. The H1 haplotype of the MAPT gene had already been associated with the pathogenesis of parkinsonism tauopathies as progressive supranuclear palsy and corticobasal degeneration [12]. Subsequently, the question arose whether H1 homozygosity would be associated with an increased risk of PD as well. So far, studies, [13-26] have mostly observed an increase in the frequency of the $\mathrm{H} 1 \mathrm{H} 1$ genotype in patients with PD but they did not always reach levels of statistical significance (for review see Zabetian et al., 2007) [27].

Originally, genetic analysis in MAPT was done by differentiating between $\mathrm{H} 1$ and $\mathrm{H} 2$ haplotypes. This has been done by analyzing an intron 9 insertion/deletion polymorphism, with the 238 bp deletion being characteristic of the $\mathrm{H} 2$ haplotype [8]. The $\mathrm{H} 1$ haplotype is more prevalent in Caucasians [28]. Therefore, sub-haplotype analysis for $\mathrm{H} 1$ carriers has been conducted by investigating several SNPs $[16,17,25,27,29-31]$. A positive association between $\mathrm{H} 1$ sub-haplotypes and PD was first reported in Norwegian patients,[30] involving SNPs rs242562 (G/A) and rs2435207 (G/A). The 'A-A' sub-haplotype for these SNPs was significantly associated with PD in this Norwegian cohort, while the 'G-A' sub-haplotype for the same SNPs was significantly represented in cases compared to controls in a Greek study [16]. However, in another independent study in Greek patients a moderate association with PD was identified for a different SNP, namely rs3785883 [17].
Since the two previous studies in Greek PD patients gave conflicting results, $[16,17]$ we sought to provide more information on whether the H1 haplotype and H1 subhaplotypes are associated with PD in this ethnic group of patients. We tested a cohort of PD patients and controls from a different site (Athens) of Greece than the previous two studies which were based on samples from Northern and Central Greece.

\section{Methods \\ Subjects}

We recruited 122 unrelated sporadic PD patients (mean age: $64.5 \pm 10.7$ years, $41 \%$ female, mean age of diagnosis: 51.5 years). The patients were of Greek ancestry and were selected by G.T. from the Department of Neurology, "G. Gennimatas" General Hospital, Athens, Greece. All patients had idiopathic PD and did not suffer from other neurological diseases. The process of sample collection did not include any intervention that is not part of any common clinical practice. Idiopathic Parkinson's disease (PD) was diagnosed according to the criteria of the UK Parkinson's Disease Society Brain Bank. The use of the UKPDS standard diagnostic criteria has been shown to increase diagnostic accuracy reaching levels of up to $90 \%$ [32]. The PD symptoms were quantified by applying Part III of the Unified Parkinson's Disease Rating Scale (UPDRS) [33] score. The control group consisted of 123 unrelated individuals (mean age: $63.7 \pm 17.2,33.3 \%$ female) who were of Greek ancestry as well. The control subjects donated blood during their treatment inAthens Trauma Hospital KAT, and in the Onassis Cardiac Surgery Center, Athens, Greece. The ethics review committees of the hospitals approved the study and written informed consent was obtained from all subjects.

\section{Selection of polymorphisms}

Our primary objective was to select MAPT polymorphisms which were previously suggested to contribute to the risk of developing idiopathic PD in Greek subjects. Therefore, we focussed on the $\mathrm{H} 1 / \mathrm{H} 2$ insertion/deletion polymorphism, rs242562, rs2435207, and rs3785883 and their sub-haplotypes, which were associated with PD in Greek patients [16,17]. Furthermore, we aimed to provide more data on MAPT variants with a potential functional role on the regulation of MAPT in tauopathies, since increased expression of $\mathrm{H} 1$ haplotype has been suggested as a mechanism of PD susceptibility [20]. SNP rs242557 has been implicated as a functional variant affecting transcriptional activity of tau in patients with Alzheimer's disease [34].

The SNP rs242557 was reported to be strongly associated with rs242562 $\left(r^{2}=0.96\right)$ by Zabetian et al. [27]. Nevertheless, taking into account its potential functional role we analyzed rs242557 in our study. It turned out that 
rs242557 was in complete LD with rs242562 among our $\mathrm{H} 1 \mathrm{H} 1$ subgroup of patients. The latter SNP is included in a three-locus clade containing also rs 3785883 and rs2471738, which has been strongly associated with the tauopathies in genetic studies [35] and in a quantitive trait analysis in Alzheimer's disease [34]. The strongest twolocus haplotype identified having a significant effect on tau levels in the Alzheimer's disease study was the one containing both rs 242557 and rs 3785883 .

Overall, we have analyzed 5 polymorphisms at MAPT including the $\mathrm{H} 1 / \mathrm{H} 2$ polymorphism, rs242562, rs2435207, rs242557, and rs3785883. We did not genotype rs 2471738 which is also included in the three-locus haplotype analysis previously referred, because it is known that this SNP is in strong LD with rs2435207 according to the study by Zabetian et al. who reported D' $=0.98$ in PD patients and $D^{\prime}=0.97$ in controls [27]. Taken together we were able to represent the previously referred two and three-locus functional sub-haplotypes by the already selected SNPs.

\section{Genetic analysis of $\mathrm{HI}$ and $\mathrm{H} 2$ haplotype}

Blood samples were drawn for DNA extraction, using the QIAamp DNA Blood Mini Kit (Qiagen GmbH, Hilden, Germany) and following the manufacturer's protocol, from patients and controls.

The H1/H2 haplotype differentiation was based on the insertion/deletion polymorphism and has been performed as reported by Baker et al.,[8] with minor modifications (Table 1).

Further genetic analysis in $\mathrm{H} 1 \mathrm{H} 1$ carriers was performed by genetic determination of rs242562, rs2435207, rs3785883 and rs242557. The ABI Prism ${ }^{\circledR} 7000$ SDS instrument in conjunction with the ABI TaqMan Universal Master Mix was used to perform the assays obtained from Applied Biosystems (Applied Biosystems, Foster City, CA, USA). Data were analyzed using the ABI Prism ${ }^{\circledR}$ 7000 SDS 1.0 Software (Perkin-Elmer, Applied Biosystems Division). Correctness of genotyping results was confirmed by sequencing on an ABI 3100 automatic sequencer using the Big-Dye Terminator Cycle Sequencing Ready Reaction Kit (Applied Biosystems, Foster City, CA, USA), for SNPs rs242562 and rs2435207. Therefore, specific fragments involving rs242562 and rs2435207 were amplified by PCR (Table 1). Prior to sequencing, reaction mixtures were purified with a PCR Purification Kit (Qiagen GmbH, Hilden, Germany). For SNP rs3785883 accuracy of genotypes was evaluated by repeated genotyping of one half of the samples.

\section{Statistical analysis}

A $\chi^{2}$-test was used to compare the allele frequency of each variant with that expected for a population in HardyWeinberg equilibrium. Fisher's exact test was used to compare $\mathrm{H} 1 \mathrm{H} 1, \mathrm{H} 1 \mathrm{H} 2$, and $\mathrm{H} 2 \mathrm{H} 2$ genotype distribution between cases and control.

Odds ratios (OR) were calculated with 95\% confidence intervals (CI) and exact two-sided $P$-values, using the SPSS 15.0 program for Windows. Logistic regression analysis was conducted to adjust for sex differences. The same statistical procedure was used for genetic analysis of SNPs rs242562, rs2435207 and rs3785883. In addition, the square of the correlation coefficient $\left(\mathrm{R}^{2}\right)$ and $\mathrm{D}^{\prime}$ linkage disequilibrium (LD) was calculated pairwise between H1SNPs in cases and control subjects, using Haploview 4.1 [36]. The PHASE 2.0 software [37] was used for estimating the frequencies of the sub-haplotypes in $\mathrm{H} 1$ homozygous patients and controls. $P$-values were considered significant at $P<0.05$.

\section{Results \\ $\mathrm{HI}$ and $\mathbf{H} \mathbf{2}$ haplotype analysis}

The MAPT genotype distribution in PD patients and controls is summarized in Table 2 . The observed frequencies do not deviate from those predicted by Hardy-Weinberg equilibrium (Table 2) and were comparable to those previously reported in Caucasians [28]. The H1H1 genotype was significantly associated with PD (OR for H1H1 vs. H1H2 and H2H2: $1.566 ; 95 \% \mathrm{CI}: 1.137-2.157 ; P=$ $0.006)$. After adjustment for sex, the strong association with $\mathrm{H} 1 \mathrm{H} 1$ remained (OR for $\mathrm{H} 1 \mathrm{H} 1$ vs. $\mathrm{H} 1 \mathrm{H} 2$ and $\mathrm{H} 2 \mathrm{H} 2$ : 2.105; 95\% CI: 1.250-3.546; $P=0.005)$. Subsequently,

Table I: PCR-conditions and sequences of HI-SNP-specific primers.

\begin{tabular}{|c|c|c|}
\hline Primer & Sequences & PCR-conditions \\
\hline $\begin{array}{l}\text { HIF } \\
\text { HIR }\end{array}$ & $\begin{array}{l}\text { 5'-GGA AGA CGT TCT CAC TGA TCT G-3' } \\
\text { 5'-AGG AGT CTG GCT TCA GTC TCT C-3' }\end{array}$ & $95^{\circ} \mathrm{C} 5 \mathrm{~min}, 35 \times\left(95^{\circ} \mathrm{C} 30 \mathrm{~s}, 55^{\circ} \mathrm{C} 30 \mathrm{~s}, 72^{\circ} \mathrm{C} 30 \mathrm{~s}\right), 72^{\circ} \mathrm{C} 10 \mathrm{~min}$ \\
\hline $\begin{array}{l}\text { rs242562 F } \\
\text { rs242562 R }\end{array}$ & $\begin{array}{l}\text { 5'-GGC GAT TCC GCT GAG TCA CC-3' } \\
\text { 5'-GGC CCT GCT GGA GTC AAG AG-3' }\end{array}$ & $95^{\circ} \mathrm{C} 5 \mathrm{~min}, 35 \times\left(95^{\circ} \mathrm{C} 30 \mathrm{~s}, 62^{\circ} \mathrm{C} 30 \mathrm{~s}, 72^{\circ} \mathrm{C} 30 \mathrm{~s}\right), 72^{\circ} \mathrm{C} 10 \mathrm{~min}$ \\
\hline $\begin{array}{l}\text { rs2435207 F } \\
\text { rs2435207 R }\end{array}$ & $\begin{array}{l}\text { 5'-CTG AGG GCC GTC ACT GTC TG-3' } \\
\text { 5'-CCT CAA GCC CAT TCT CTG AC-3' }\end{array}$ & $95^{\circ} \mathrm{C} 5 \mathrm{~min}, 35 \times\left(95^{\circ} \mathrm{C} 30 \mathrm{~s}, 58^{\circ} \mathrm{C} 30 \mathrm{~s}, 72^{\circ} \mathrm{C} 30 \mathrm{~s}\right), 72^{\circ} \mathrm{C} 10 \mathrm{~min}$ \\
\hline
\end{tabular}

F, forward; R, reverse; SNP, single-nucleotide polymorphisms. 
Table 2: MAPT genotype frequencies in Parkinson's Disease.

\begin{tabular}{|c|c|c|c|c|c|c|c|}
\hline & \multicolumn{4}{|c|}{ Genotype \% } & \multicolumn{3}{|c|}{$\mathrm{HIHI}$ vs. $\mathrm{HIH} 2$ and $\mathrm{H} 2 \mathrm{H} 2$} \\
\hline & $\mathrm{HIHI}$ & $\mathrm{HIH} 2$ & $\mathrm{H} 2 \mathrm{H} 2$ & $\begin{array}{l}\text { HWE } \\
\text { P-value }\end{array}$ & OR & $95 \% \mathrm{Cl}$ & $P$ value \\
\hline$\%$ cases $(n=122)$ & 68.9 & 27.9 & 3.3 & 0.971 & 1.566 & $1.137-2.157$ & 0.006 \\
\hline$\%$ controls $(n=123)$ & 51.2 & 45.5 & 3.3 & 0.128 & - & - & - \\
\hline
\end{tabular}

HWE, Hardy-Weinberg equilibrium; $P$-value, two-sided exact $p$-value from Fisher's exact test;

OR, odds ratio; $95 \% \mathrm{Cl}=95 \%$ confidence interval.

we determined $\mathrm{H} 1$ sub-haplotypes in individuals carrying the $\mathrm{H} 1 \mathrm{H} 1$ genotype, in the cohort of patients $(\mathrm{n}=84)$ and controls $(n=63)$ of our study, respectively. These results are summarized in Table 3. SNP rs242557 was in complete LD with rs242562 among our H1H1 subgroup of patients, therefore this SNP was discarded from further results analysis. The genotype and allelic distributions were also in Hardy-Weinberg equilibrium for PD patients and controls. Fisher's exact test $P$-values did not reveal any association between the rs242562, rs2435207, rs3785883 SNPs and PD. LD (calculated as D' and $\mathrm{R}^{2}$ ) among H1SNPs were similar in cases and controls, with the exception of $\mathrm{D}^{\prime}=0.76$ between rs3785883 and rs 2435207 in cases, which was also greater than the D' reported in previous studies $[25,27]$ between these two SNPs (Table 4). We also examined the distribution of $\mathrm{H} 1$ sub-haplotypes which were compiled as combinations of the three SNPs. This analysis did not reveal any significant difference in sub-haplotypes involving SNPs rs242562 (G/A) and rs2435207 (G/A) between cases and controls (Table 5), as previously reported $[16,30]$. Finally, we estimated the effect of the rest two- and three-locus sub-haplotypes defined by SNPs rs242562, rs2435207 and rs 3785883, but the results showed no association with PD (data not shown).

\section{Discussion}

Our results confirm that the distribution of the $\mathrm{H} 1$ haplotype of MAPT is an important risk factor of PD. Ôwo meta-analyses of studies on this subject supported the hypothesis that the H1 haplotype may confer susceptibility to $P D,[18,38]$ and also recent PD genetic association studies with a large sample size observed a significantly greater frequency of the $\mathrm{H} 1$ haplotype in $\mathrm{PD}$ cases compared to control subjects $[27,29,31,39]$. Reasons for studying the relationship between $\mathrm{H} 1$ haplotype and $\mathrm{PD}$ were i) the proven increased transcriptional activity of $\mathrm{H} 1 \mathrm{com}$ pared to $\mathrm{H} 2,[20]$ suggesting a possible mechanism of PD susceptibility, since overexpression of transgenic tau has been found to cause neuronal death in Drosophila with-

Table 3: SNPI and 2 genotype frequencies given as number (\%).

\begin{tabular}{|c|c|c|c|c|c|c|c|}
\hline & \multicolumn{3}{|c|}{ Cases $(n=84)$} & \multicolumn{3}{|c|}{ Controls $(n=63)$} & \multirow[t]{2}{*}{$P$ value } \\
\hline \multicolumn{7}{|c|}{ rs $242562^{*}, 5^{\prime}$ of exon I } & \\
\hline \multirow[t]{2}{*}{ Genotypic } & $\mathrm{G} / \mathrm{G}$ & $\mathrm{G} / \mathrm{A}$ & $\mathrm{A} / \mathrm{A}$ & $\mathrm{G} / \mathrm{G}$ & $\mathrm{G} / \mathrm{A}$ & $\mathrm{A} / \mathrm{A}$ & 0.806 \\
\hline & $27(32.1)$ & $45(53.6)$ & $12(14.3)$ & $23(36.5)$ & $30(47.6)$ & $10(15.9)$ & \\
\hline \multirow[t]{2}{*}{ Allelic } & $\mathrm{G}$ & A & & $\mathrm{G}$ & A & & 0.706 \\
\hline & $99(58.9)$ & $69(4 I .1)$ & & $76(60.3)$ & $50(39.7)$ & & \\
\hline \multicolumn{8}{|c|}{ rs3785883, Intron 3} \\
\hline \multirow[t]{2}{*}{ Genotypic } & G/G & $\mathrm{G} / \mathrm{A}$ & $\mathrm{A} / \mathrm{A}$ & $\mathrm{G} / \mathrm{G}$ & $\mathrm{G} / \mathrm{A}$ & $\mathrm{A} / \mathrm{A}$ & 0.388 \\
\hline & $53(63.1)$ & $29(34.5)$ & $2(2.1)$ & $35(55.5)$ & $24(38.1)$ & $4(6.4)$ & \\
\hline \multirow[t]{2}{*}{ Allelic } & G & $A$ & & G & $A$ & & 0.239 \\
\hline & $135(80.4)$ & $33(19.6)$ & & $94(74.6)$ & $32(25.4)$ & & \\
\hline \multicolumn{8}{|c|}{ rs2435207, Intron 4} \\
\hline \multirow[t]{2}{*}{ Genotypic } & $\mathrm{G} / \mathrm{G}$ & $\mathrm{G} / \mathrm{A}$ & $\mathrm{A} / \mathrm{A}$ & $\mathrm{G} / \mathrm{G}$ & $\mathrm{G} / \mathrm{A}$ & $\mathrm{A} / \mathrm{A}$ & 0.832 \\
\hline & $34(40.5)$ & $4 I(48.8)$ & $9(10.7)$ & $28(44.5)$ & $30(47.6)$ & $5(7.9)$ & \\
\hline \multirow[t]{2}{*}{ Allelic } & G & A & & $\mathrm{G}$ & A & & 0.777 \\
\hline & $109(64.9)$ & $59(35.1)$ & & $86(68.3)$ & $40(31.7)$ & & \\
\hline
\end{tabular}

$P$-value, two-sided exact $\mathrm{p}$-value from Fisher's exact test.

* rs242557 revealed identical genotypes in cases 
Table 4: LD for HI-SNPs

\begin{tabular}{lcccc}
\hline & \multicolumn{2}{c}{ Cases $(n=84)$} & \multicolumn{2}{c}{ Controls $(n=63)$} \\
& $D^{\prime}$ & $R^{2}$ & $D^{\prime}$ & $R^{2}$ \\
\hline rs242562* vs rs3785883 & 0.136 & 0.007 & 0.005 & 0.000 \\
rs242562* vs rs2435207 & 0.361 & 0.104 & 0.340 & 0.094 \\
rs3785883 vs rs2435207 & 0.761 & 0.255 & 0.528 & 0.183 \\
\hline
\end{tabular}

Linkage Disequilibrium (LD) measured by $D^{\prime}$ and $R^{2}$.

* rs242557 revealed identical genotypes in cases

out neurofibrillary tangles,[40] and ii) a possible link between elevated $\mathrm{H} 1$ percentages among PD patients and tau mediated $\alpha$-synuclein fibrillization,[6] which is believed to play an important role in the development and progression of PD. Our findings support this line of reasoning and provide further evidence for a role of this genetic variant of MAPT as a risk factor for PD.

Nevertheless, some conflicting findings have previously been related to varying effects of $\mathrm{H} 1$ in different ethnic populations $[17,25]$. Our study is the sixth conducted in a southern European population (3 Greek, 1 Italian, 1 Spanish, 1 Serbian) and the third in a Greek population. It is worth noting that five of these studies have also confirmed an association of haplotype H1 with PD while one Greek population study [17] failed to demonstrate this association. Generally, lack of reproducibility among case-control studies regarding the role of $\mathrm{H} 1 \mathrm{H} 1$ genotype in PD can be explained by two factors. First, small sample sizes sometimes lead to underpowered studies. This is not always a satisfactory explanation since the association was not confirmed in a rather large group $(n=418)$ of German origin [25]. Moreover, the relevance of genetic risk factors could vary between different ethnic populations. The possibility of ethnic background influence among white Caucasians to explain the contradictory results has been discussed previously [25]. The genetic association between the overall MAPT locus and PD has been well established $[18,31,41]$. Other genes of the MAPT region either within the MAPT locus (e.g. Saitohin) or within the extended H1 haplotype (e.g.KIAA1267), have been also implicated in PD $[31,42]$. The genetic dissection of the
MAPT locus and its role in PD is still a major challenge, because of the complexity of this genomic region. The latter is a result of both the complex haplotype structure and the fact that the MAPT locus contains other genes which are yet not fully characterized. Moreover, it is currently unclear whether the influence of these genes could vary among different ethnicities due to varying allele and haplotype frequencies within the MAPT locus. Our data contribute to the evaluation of MAPT in Greek patients among which the available studies revealed some contradictory results $[16,17]$.

In the previous study in Greek patients a role of gender effects on the association between MAPT and PD was suggested [16]. The authors found in separate analysis according to sex a significant association between $\mathrm{H} 1 \mathrm{H} 1$ and PD in men but not in women. This could point to a potential sex specific effect of genetic MAPT variation to PD susceptibility. However, it may be also related to a reduced statistical power in subgroup analysis. Hence, when we performed a separate statistical analysis for men and women in our cohort we also found a significant effect in 72 male patients but no significant effect in 50 female patients. In contrast, in logistic regression analysis we found no significant effect of sex status affecting the significant association between $\mathrm{H} 1 \mathrm{H} 1$ genotype in the overall cohort. Our latter finding is in agreement with a large US case-control cohort study that did not support a sex specific effect [27].

Efforts were made in previous studies to analyze whether specific genetic variants in MAPT within the H1 haplotype are responsible for the increased PD risk. Risk variants on different $\mathrm{H} 1$ sub-haplotypes were found to contribute to population risk for PD. In each case the variant was found to be a different one: rs242562-rs2435207 G-A sub-haplotype in a Greek population,[16] A-A sub-haplotype for the same SNPs in a Norwegian population, [30] rs3785883 in another Greek population,[17] rs7521 and rs242557 in a Finnish population,[17] rs2471738 in a UK population [43] and finally a six-SNP sub-haplotype of H1 (hCV3202946, rs1800547, rs3785883, rs2435207, rs11568305, rs1078997) in a multicenter study conducted in Europe and North America [31]. On the other

Table 5: Frequencies of sub-haplotypes (HI-SNPs rs242562-rs2435207) in study groups

\begin{tabular}{ccccc}
\hline Sub-haplotype & Cases Frequency & Controls Frequency & P-value & OR $(95 \% \mathrm{Cl})$ \\
\hline G-G-HI & 0.482 & 0.500 & 0.814 & $0.960(0.737-1.250)$ \\
G-A-HI & 0.107 & 0.103 & 1.000 & $1.025(0.662-1.586)$ \\
A-G-HI & 0.167 & 0.183 & 0.757 & $0.940(0.671-1.316)$ \\
A-A-HI & 0.244 & 0.214 & 0.579 & $1.103(0.795-1.532)$ \\
\hline
\end{tabular}

$P$-value, two-sided exact $P$-value from Fisher's exact test; $\mathrm{OR}$, odds ratio; $95 \% \mathrm{Cl}=95 \%$ confidence interval. 
hand, Goris et al.,[29] and Winkler et al.,[25] did not find any association between PD and specific H1 sub-haplotypes. Taken together, published data failed to identify a common sub-haplotype within the $\mathrm{H} 1$ haplotype so far. In the case of sub-haplotypes analyses, the problem of statistical power might become even more important as the sample sizes are even smaller, since in some studies only the $\mathrm{H} 1 \mathrm{H} 1$ carriers are examined. In this regard, we tried to add more data to the previous finding [16] in the Greek population by examining the same sub-haplotypes in the same ethnic background, but in patients obtained from a different site and geographic region. Our data reveal an almost identical percentage of rs242562 and rs2435207 genotypes and haplotypes among $\mathrm{H} 1 \mathrm{H} 1$ patients and controls, showing that the risk does not seem to arise from one of the two previously reported sub-haplotypes composed by these SNPs. Furthermore, some of the sub-haplotypes defined by SNPs rs242562, rs2435207 rs3785883, which represented two and three-locus functional subhaplotypes for the tauopathies, [35] do not seem to alter disease risk in Parkinson as it was also shown in other studies, $[25,43]$ suggesting that Parkinson does not share the same pathways with the tauopathies.

A limitation of our study results from the small sample size and limited statistical power. As a consequence we examined, however, the consistency of our results by genotyping the $\mathrm{H} 1 \mathrm{H} 2$ subjects of our cohorts (data not shown), namely 118 patients and 119 control individuals as previously suggested [35]. In this analysis we still did not identify any effect of single SNPs or SNP sub-haplotypes. In addition, although we used a well established standardized clinical scoring system for PD diagnosis misclassification of PD patients by lack of histological confirmation represents a potential other limitation of our study. Nevertheless, recently it was shown [43] in pathologically confirmed PD cases that the association of MAPT with the disease is chiefly driven by the $\mathrm{H} 1 / \mathrm{H} 2$ division alone, which is in agreement with our results.

Thus, in order to dissect the genetic and molecular basis of the H1 haplotype in PD, additional studies and in larger samples are necessary. Nonetheless, since MAPT gene alters PD risk, identification of gene-gene or gene-environment interactions, contributing to accelerated degeneration of the nigrostriatal dopaminergic neurons, should be explored. Such knowledge about the underlying mechanisms could open up new arenas for early diagnostic and therapeutic interventions in this important neurodegenerative disease $[44,45]$.

\section{Conclusion}

Our data show strong evidence of an association between the H1/H1 genotype and PD in Greek population, however the SNPs rs242562, rs2435207 and rs3785883 within the H1 haplotype do not seem to alter susceptibility for PD.

\section{Competing interests}

The authors declare that they have no competing interests.

\section{Authors' contributions}

NR collected the samples, executed the genetic studies, performed the statistical analysis, interpreted the data and wrote the first draft of the manuscript. JB participated in the design and organisation of the project, helped to execute the genetic studies, helped to analyse the data and participated in the review and critique of the manuscript. GT carried out the examination of the patients and the collection of the samples and helped to review the manuscript. AO helped to analyse the data and participated in the critique of the manuscript. ND participated in the design of the project, helped to collect the samples, worked on data analysis and helped to draft the manuscript. RK developed the idea of the research initially, supervised the project and critically revised all the submitted material. All authors read and approved the final manuscript.

\section{Acknowledgements}

We acknowledge the contributions of Jana Flügge for haplotype analysis and Chaido Dafni for sample collection.

\section{References}

I. Mizuno Y: Second International Symposium on the Treatment of Parkinson's Disease. Neurology 1998, 5 I:SI.

2. Jankovic J: Parkinson's disease: clinical features and diagnosis. J Neurol Neurosurg Psychiatry 2008, 79:368-376.

3. Forno LS: Neuropathology of Parkinson's disease. J Neuropathol Exp Neurol 1996, 55:259-272.

4. Volles MJ, Lansbury PT Jr: Zeroing in on the pathogenic form of alpha-synuclein and its mechanism of neurotoxicity in Parkinson's disease. Biochemistry 2003, 42:787I-7878.

5. Jensen PH, Hager H, Nielsen MS, Hojrup P, Gliemann J, Jakes R: alpha-synuclein binds to $\mathrm{Tau}$ and stimulates the protein kinase A-catalyzed tau phosphorylation of serine residues 262 and 356. J Biol Chem 1999, 274:2548I-25489.

6. Giasson BI, Forman MS, Higuchi M, Golbe LI, Graves CL, Kotzbauer PT, Trojanowski JQ, Lee VM: Initiation and synergistic fibrillization of tau and alpha-synuclein. Science 2003, 300:636-640.

7. Higuchi M, Lee VM, Trojanowski JQ: Tau and axonopathy in neurodegenerative disorders. Neuromolecular Med 2002, 2: I3I-I50.

8. Baker M, Litvan I, Houlden H, Adamson J, Dickson D, Perez-Tur J, Hardy J, Lynch T, Bigio E, Hutton M: Association of an extended haplotype in the tau gene with progressive supranuclear palsy. Hum Mol Genet 1999, 8:71 I-7II5.

9. Stefansson $\mathrm{H}$, Helgason A, Thorleifsson $G$, Steinthorsdottir $V$, Masson G, Barnard J, Baker A, Jonasdottir A, Ingason A, Gudnadottir VG, Desnica N, Hicks A, Gylfason A, Gudbjartsson DF, Jonsdottir GM, Sainz J, Agnarsson K, Birgisdottir B, Ghosh S, Olafsdottir A, Cazier JB, Kristjansson K, Frigge ML, Thorgeirsson TE, Gulcher JR, Kong A, Stefansson $\mathrm{K}$ : A common inversion under selection in Europeans. Nat Genet 2005, 37: 129-137.

10. Pastor P, Ezquerra M, Tolosa E, Muñoz E, Martí MJ, Valldeoriola F, Molinuevo JL, Calopa M, Oliva R: Further extension of the $\mathbf{H I}$ haplotype associated with progressive supranuclear palsy. Mov Disord 2002, 17:550-556.

II. Scott WK, Nance MA, Watts RL, Hubble JP, Koller WC, Lyons K, Pahwa R, Stern MB, Colcher A, Hiner BC, Jankovic J, Ondo WG, Allen FH Jr, Goetz CG, Small GW, Masterman D, Mastaglia F, Laing NG, Stajich JM, Slotterbeck B, Booze MW, Ribble RC, Rampersaud E, 
West SG, Gibson RA, Middleton LT, Roses AD, Haines JL, Scott BL, Vance JM, Pericak-Vance MA: Complete genomic screen in Parkinson disease: evidence for multiple genes. JAMA 200I, 286:2239-2244.

12. Galpern WR, Lang AE: Interface between tauopathies and synucleinopathies: a tale of two proteins. Ann Neurol 2006, 59:449-458

13. Clark LN, Levy G, Tang MX, Mejia-Santana H, Ciappa A, Tycko B, Cote LJ, Louis ED, Mayeux R, Marder K: The Saitohin 'Q7R' polymorphism and tau haplotype in multi-ethnic Alzheimer disease and Parkinson's disease cohorts. Neurosci Lett 2003 347: $17-20$.

14. de Silva R, Hardy J, Crook J, Khan N, Graham EA, Morris CM, Wood NW, Lees AJ: The tau locus is not significantly associated with pathologically confirmed sporadic Parkinson's disease. Neurosci Lett 2002, 330:20I-203.

15. Farrer M, Skipper L, Berg M, Bisceglio G, Hanson M, Hardy J, Adam A, Gwinn-Hardy K, Aasly J: The tau $\mathrm{HI}$ haplotype is associated with Parkinson's disease in the Norwegian population. Neurosci Lett 2002, 322:83-86.

16. Fidani L, Kalinderi K, Bostantjopoulou S, Clarimon J, Goulas A, Katsarou Z, Hardy J, Kotsis A: Association of the Tau haplotype with Parkinson's disease in the Greek population. Mov Disord 2006, 21:1036-1039.

17. Fung HC, Xiromerisiou G, Gibbs JR, Wu YR, Eerola J, Gourbali V, Hellström O, Chen CM, Duckworth J, Papadimitriou A, Tienari PJ, Hadjigeorgiou GM, Hardy J, Singleton AB: Association of tau haplotype-tagging polymorphisms with Parkinson's disease in diverse ethnic Parkinson's disease cohorts. Neurodegener Dis 2006, 3:327-333.

18. Healy DG, Abou-Sleiman PM, Lees AJ, Casas JP, Quinn N, Bhatia K, Hingorani AD, Wood NW: Tau gene and Parkinson's disease: a case-control study and meta-analysis. J Neurol Neurosurg Psychiatry 2004, 75:962-965.

19. Johansson A, Zetterberg H, Hakansson A, Nissbrandt H, Blennow K: TAU haplotype and the Saitohin Q7R gene polymorphism do not influence CSF Tau in Alzheimer's disease and are not associated with frontotemporal dementia or Parkinson's disease. Neurodegener Dis 2005, 2:28-35.

20. Kwok JB, Teber ET, Loy C, Hallupp M, Nicholson G, Mellick GD, Buchanan DD, Silburn PA, Schofield PR: Tau haplotypes regulate transcription and are associated with Parkinson's disease. Ann Neurol 2004, 55:329-334.

21. Levecque C, Elbaz A, Clavel J, Vidal JS, Amouyel P, Alpérovitch A, Tzourio C, Chartier-Harlin MC: Association of polymorphisms in the Tau and Saitohin genes with Parkinson's disease. J Neurol Neurosurg Psychiatry 2004, 75:478-480.

22. Maraganore DM, Hernandez DG, Singleton AB, Farrer MJ, McDonnell SK, Hutton ML, Hardy JA, Rocca WA: Case-Control study of the extended tau gene haplotype in Parkinson's disease. Ann Neurol 200I, 50:658-66I.

23. Pastor P, Ezquerra M, Munoz E, Martí MJ, Blesa R, Tolosa E, Oliva R: Significant association between the tau gene AO/AO genotype and Parkinson's disease. Ann Neurol 2000, 47:242-245.

24. Peplonska B, Zekanowski C, Religa D, Czyzewski K, Styczyñska M, Pfeffer A, Gabryelewicz T, Gołebiowski M, Luczywek E, Wasiak B, Barczak A, Chodakowska M, Barcikowska M, Kuźnicki J: Strong association between Saitohin gene polymorphism and tau haplotype in the Polish population. Neurosci Lett 2003, 348: $163-166$.

25. Winkler S, Konig IR, Lohmann-Hedrich K, Vieregge P, Kostic V, Klein $\mathrm{C}$ : Role of ethnicity on the association of MAPT HI haplotypes and subhaplotypes in Parkinson's disease. Eur J Hum Genet 2007, 15:1163-1168.

26. Zappia M, Annesi G, Nicoletti G, Serra P, Arabia G, Pugliese P, Messina D, Caracciolo M, Romeo N, Annesi F, Pasqua AA, Spadafora P, Civitelli D, Romeo N, Epifanio A, Morgante L, Quattrone A: Association of tau gene polymorphism with Parkinson's disease. Neurol Sci 2003, 24:223-224.

27. Zabetian CP, Hutter CM, Factor SA, Nutt JG, Higgins DS, Griffith A, Roberts JW, Leis BC, Kay DM, Yearout D, Montimurro JS, Edwards $\mathrm{KL}$, Samii A, Payami H: Association analysis of MAPT HI haplotype and subhaplotypes in Parkinson's disease. Ann Neurol 2007, 62:137-144.

28. Evans W, Fung HC, Steele J, Eerola J, Tienari P, Pittman A, Silva R, Myers A, Vrieze FW, Singleton A, Hardy J: The tau H2 haplotype is almost exclusively Caucasian in origin. Neurosci Lett 2004, 369:183-185

29. Goris A, Williams-Gray CH, Clark GR, Foltynie T, Lewis SJ, Brown J, Ban M, Spillantini MG, Compston A, Burn DJ, Chinnery PF, Barker RA, Sawcer SJ: Tau and alpha-synuclein in susceptibility to, and dementia in, Parkinson's disease. Ann Neurol 2007, 62:145-153.

30. Skipper L, Wilkes K, Toft M, Baker M, Lincoln S, Hulihan M, Ross OA, Hutton M, Aasly J, Farrer M: Linkage disequilibrium and association of MAPT HI in Parkinson disease. Am J Hum Genet 2004, 75:669-677.

3I. Tobin JE, Latourelle JC, Lew MF, Klein C, Suchowersky O, Shill HA, Golbe LI, Mark MH, Growdon JH, Wooten GF, Racette BA, Perlmutter JS, Watts R, Guttman M, Baker KB, Goldwurm S, Pezzoli G, Singer C, Saint-Hilaire MH, Hendricks AE, Williamson S, Nagle MW, WilkJB, Massood T, Laramie JM, DeStefano AL, Litvan I, Nicholson G, Corbett A, Isaacson S, Burn DJ, Chinnery PF, Pramstaller PP, Sherman S, Alhinti J, Drasby E, Nance M, Moller AT, Ostergaard K, Roxburgh R, Snow B, Slevin JT, Cambi F, Gusella JF, Myers RH: Haplotypes and gene expression implicate the MAPT region for Parkinson disease. The GenePD Study. Neurology 2008, 71:28-34.

32. Hughes AJ, Daniel SE, Lees AJ: Improved accuracy of clinical diagnosis of Lewy body Parkinson's disease. Neurology 200I, 57:1497-9.

33. Goetz CG, Fahn S, Martinez-Martin P, Poewe W, Sampaio C, Stebbins GT, Stern MB, Tilley BC, Dodel R, Dubois B, Holloway R, Jankovic J, Kulisevsky J, Lang AE, Lees A, Leurgans S, LeWitt PA, Nyenhuis D, Olanow CW, Rascol O, Schrag A, Teresi JA, Van Hilten JJ, LaPelle N: Movement Disorder Society-sponsored revision of the Unified Parkinson's Disease Rating Scale (MDS-UPDRS): Process, format, and clinimetric testing plan. Mov Disord 2007, 22:4I-47.

34. Laws SM, Friedrich P, Diehl-Schmid J, Müller J, Eisele T, Bäuml J, Förstl $H$, Kurz A, Riemenschneider M: Fine mapping of the MAPT locus using quantitative trait analysis indentifies possible causal variants in Alzheimer's disease. Mol Psychiatry 2007, I 2:5 I 0-5 I 7.

35. Pittman AM, Myers AJ, Abou-Sleiman P, Fung HC, Kaleem M, Marlowe L, Duckworth J, Leung D, Williams D, Kilford L, Thomas N, Morris CM, Dickson D, Wood NW, Hardy J, Lees AJ, de Silva R: Linkage disequilibrium fine mapping and haplotype association analysis of the tau gene in progressive supranuclear palsy and corticobasal degeneration. J Med Genet 2005, 42:837-46.

36. Barrett JC, Fry B, Maller J, Daly MJ: Haploview: analysis and visualization of LD and haplotype maps. Bioinformatics 2005, 21:263-265.

37. Stephens M, Smith NJ, Donnelly P: A new statistical method for haplotype reconstruction from population data. Am J Hum Genet 200I, 68:978-989.

38. Zhang J, Song $Y$, Chen H, Fan D: The tau gene haplotype $\mathbf{~ I ~ c o n - ~}$ fers a susceptibility to Parkinson's disease. Eur Neurol 2005, 53:|5-2|

39. McCulloch CC, Kay DM, Factor SA, Samii A, Nutt JG, Higgins DS, Griffith A, Roberts JW, Leis BC, Montimurro JS, Zabetian CP, Payami $\mathrm{H}$ : Exploring gene-environment interactions in Parkinson's disease. Hum Genet 2008, I 23:257-265.

40. Wittmann CW, Wszolek MF, Shulman JM, Salvaterra PM, Lewis J, Hutton M, Feany MB: Tauopathy in Drosophila: neurodegeneration without neurofibrillary tangles. Science 2001, 293:7|I-7|4

4I. Pankratz N, Wilk JB, Latourelle JC, DeStefano AL, Halter C, Pugh EW, Doheny KF, Gusella JF, Nichols WC, Foroud T, Myers RH, PSG-PROGENI and GenePD Investigators, Coordinators and Molecular Genetic Laboratories: Genomewide association study for susceptibility genes contributing to familial Parkinson disease. Hum Genet 2009, I 24:593-605.

42. Oliveira SA, Scott WK, Zhang F, Stajich JM, Fujiwara K, Hauser M, Scott BL, Pericak-Vance MA, Vance JM, Martin ER: Linkage disequilibrium and haplotype tagging polymorphisms in the Tau $\mathrm{HI}$ haplotype. Neurogenetics 2004, 3:147-55

43. Vandrovcova J, Pittman AM, Malzer E, Abou-Sleiman PM, Lees AJ, Wood NW, de Silva R: Association of MAPT haplotype-tagging SNPs with sporadic Parkinson's disease. Neurobiol Aging 2007 in press.

44. Schubert M, Breakefield X, Federoff H, Frederickson RM, Lowenstein PR: Gene delivery to the nervous system. Mol Ther 2008, 16:640-646. 
45. Dass B, Olanow CW, Kordower JH: Gene transfer of trophic factors and stem cell grafting as treatments for Parkinson's disease. Neurology 2006, 66:589-103.

\section{Pre-publication history}

The pre-publication history for this paper can be accessed here:

http://www.biomedcentral.com/1471-2377/9/26/prepub

Publish with Bio Med Central and every scientist can read your work free of charge

"BioMed Central will be the most significant development for disseminating the results of biomedical research in our lifetime. " Sir Paul Nurse, Cancer Research UK

Your research papers will be:

- available free of charge to the entire biomedical community

- peer reviewed and published immediately upon acceptance

- cited in PubMed and archived on PubMed Central

- yours - you keep the copyright 